\title{
Estimation on the Income Elasticity of Household Demand for Sweet Potatoes, Ipomoea batatas and Yams, Dioscorea Spp.'
}

\author{
Zita M. Diaz de Sumaza and Lillian Rodríguez de Zapata ${ }^{2}$
}

\section{INTRODUCTION}

Per capita consumption of yams in Puerto Rico declined from 11.5 pounds in 1956 to 9.6 pounds in 1969; of sweet potatoes, from 21.8 to 9.8 pounds (1). The movement of population from rural to urban areas, changes in the composition of the population, and advances in consumer income are among the reasons for changes in consumption of yams and sweet potatoes during the above span of time.

The objectives of this study were to develop estimates of the incomeconsumption elasticity of household demand for swect potatoes and yams, and to identify the relationship between consumption of these products and variates such as rural-urban location, houschold size, number of meals taken away from home, home production and product prices. The analysis is based on information contained in a collection of 1,021-family food budgets obtained in 1961-62 by the Agricultural Experiment Station of the University of Puerto Rico.

\section{METIODOLOGY}

Income elasticity is measured by submitting consumption and income data to an appropriate mathematical model of which income forms an independent variable. If the model is properly selected and if income is related to home consumption of yams and sweet potatoes, the model should produce a statistically significant coefficient for the income variate. The same generalization holds for other variables.

The least-square regression approach was used to develop estimates of income elasticity and to measure the influence of household size on the consumption of sweet potatoes and yams. Four basic mathematical models were used to study the form of the income-consumption relation (2). Each model was applied to all houscholds in the sample, as well as to urban and

1 Submitted to the Editorial Board September 21, 1971.

2 Research Assistant and Assistant Economist, respectively, Agricultural Experiment. Station, Mayagüez Campus, University of Puerto Rico, Río Piedras, P.R. The authors wish to express gratitude to all those persons and institutions who contributed to this work. Among these, special mention must be made of Dr. Robert $O$. Herrman, Associate Professor at Penn State University and Chairman of the senior author's graduate committee, for his valuable advice throughout the preparation of this study. 
rural houscholds separately. Related studies, as well as cross-tabulation of the data, served as guides in the selection of the models. All models assume that the consumption function for yams and sweet potatoes may be postulated as:

$Y=f\left(X_{1}, X_{2}\right)$ where:

$Y=$ Annual quantity purchased, in pounds per household

$X_{1}=$ Annual family income, in dollars

$X_{2}=$ Family size, in actual head count

The various models used to interpret consumption information are shown in the following tabulation:

Model

Logarithmic

Semi-logarithmic

Quadratic

Inverse

$$
\begin{gathered}
\text { Function } \\
\log Y=a+b_{1} \log X_{1} \\
Y=a+b_{1} \log X_{1} \\
Y=a+b_{1} X_{1}+b_{2} X_{1}{ }^{2} \\
Y=a-\frac{b_{1}}{\bar{X}_{1}}
\end{gathered}
$$

The choice of equation used to describe household demand for yams and sweet potatoes was based on the size of the multiple regression coefficient, $R^{2}$, and related statistical tests of significance. The significance of the percentage variation explained by each regression, as shown by $R^{2}$, was evaluated by use of $F$ tests. The $F$ test was also used to test the significance of the differences in $R^{2}$ obtained from successive addition of new variables. In each case, the reduction in sum of squares due to the added variables was tested against the mean square for error obtained after the new variable was added.

Based on the criteria provided by these tests, individual models were selected for rural, urban, and all houscholds in regard to their consumption of sweet potatoes and yams.

\section{RESULTS}

\section{PATTERN OF PURCHASE OF SWEET POTATOES AND YAMS}

Annual purchase of sweet potatoes per family among those who reported purchasing them was 58 and 72 pounds in the urban and rural areas, respectively, with an overall average of 63 pounds (table 1). In urban areas the average increased from 38 pounds per family, among households with annual incomes of less than $\$ 1,000$, to 66 pounds among those with annual incomes between $\$ 3,000$ and $\$ 4,999$. However, quantity purchased per family decreased to 61 pounds among urban households with incomes of $\$ 5,000$ or more. In the rural areas, the number of pounds purchased annually increased from 56 per family among houscholds with incomes of less than $\$ 1,000$ to 102 among those with annual incomes between $\$ 3,000$ and $\$ 4,999$. As in the previous case, quantity purchased per family de- 
creased to 88 pounds among rural households with incomes of $\$ 5,000$ or more.

The annual purchase of swect potatoes by urban households increased from 25 to 69 pounds as family size increased from 1 to 9 or more. A general increase in consumption with size of family up to 8 members was also noticed in the rural areas.

Annual purchases of yams per family by those who reported purchasing them averaged 62 and 111 pounds in the urban and rural areas, respec-

TABLE 1.-Quantily reported by families that purchased sweet polatoes, by Rural and Urban Area, income categories, and family size, Puerlo Rico, 1962

\begin{tabular}{|c|c|c|c|c|c|c|}
\hline \multirow{2}{*}{ Item } & \multicolumn{2}{|c|}{ Urban Area } & \multicolumn{2}{|c|}{ Rural Area } & \multicolumn{2}{|c|}{ All Areas } \\
\hline & Family & Person & Family & Person & Family & Person \\
\hline & \multicolumn{6}{|c|}{ Pounds per year } \\
\hline \multicolumn{7}{|l|}{$\begin{array}{l}\text { Annual family income } \\
\text { (dollars) }\end{array}$} \\
\hline Less than 1,000 & 38 & 9 & 56 & 12 & 49 & 11 \\
\hline 1,000 to 2,999 & 58 & 11 & 75 & 12 & 65 & 12 \\
\hline 3,000 to 4,999 & 66 & 12 & 102 & 15 & 74 & 13 \\
\hline 5,000 or more & 61 & 13 & 89 & 12 & 64 & 13 \\
\hline \multicolumn{7}{|l|}{$\begin{array}{l}\text { Family size (number } \\
\text { of persons) }\end{array}$} \\
\hline 1 & 25 & 25 & 31 & 31 & 28 & 28 \\
\hline 2 & 30 & 18 & 60 & 33 & 46 & 23 \\
\hline 3 to 5 & 61 & 15 & $6 i 2$ & 15 & 61 & 15 \\
\hline 6 to 8 & 62 & 9 & 85 & 12 & 73 & 11 \\
\hline 9 or more & 69 & 7 & 74 & 7 & 71 & 7 \\
\hline $\begin{array}{l}\text { Average for all fami- } \\
\text { lies }\end{array}$ & 58 & 12 & 72 & 13 & 63 & 12 \\
\hline
\end{tabular}

tively, with an overall average of 80 pounds (table 2). In urban areas annual purchases increased an average of 48 pounds among households with annual incomes of less than $\$ 1,000$ and 70 pounds among those with annual incomes between $\$ 3,000$ and $\$ 4,999$. However, the purchase per family then decreased to 64 pounds among urban households with incomes of $\$ 5,000$ or more. In the rural areas there was a general increase in the number of pounds purchased, from 72 per family among households with annual incomes of less than $\$ 1,000$ to 164 for households with annual incomes of $\$ \tilde{i}, 000$ or more.

The annual purchase of yams by urban and rural families increased with family size. 
MULTIPLE REGRESSION ANALYSIS OF DEMAND FOR SWEET POTATOES AND YAMS

Of the various equations fitted to the data to determine whether the conclusions reached in the preceding section through tabular analysis are sustained by statistical testing, the logarithmic and semi-logarithmic functions provided the most adequate explanations of variation among households in the annual purchase of sweet potatoes (table 3). It will be noted that the $R^{2}$ values computed in this study were small, indicating a high degree of variability among households.

TABLe 2.-Quantily reporled by families that purchased yams, by Rural and Urban A rea, income calegorics, and family size, Puerto Rico, 1962

\begin{tabular}{|c|c|c|c|c|c|c|}
\hline \multirow{2}{*}{ Item } & \multicolumn{2}{|c|}{ Urban Area } & \multicolumn{2}{|c|}{ Rural Area } & \multicolumn{2}{|c|}{ All Areas } \\
\hline & Family & Person & Family & Person & Family & Person \\
\hline
\end{tabular}

Annual family income (dollars)

$\begin{array}{lllrlll}\text { Less than } 1,000 & 48 & 10 & 72 & 15 & 63 & 13 \\ 1,000 \text { to } 2,999 & 61 & 12 & 139 & 21 & 91 & 16 \\ 3,000 \text { to } 4,999 & 70 & 15 & 129 & 19 & 82 & 16 \\ 5,000 \text { or more } & 64 & 14 & 164 & 23 & 76 & 15\end{array}$

Family size (Number of persons)

\begin{tabular}{crrrrrr}
1 & 20 & 20 & 10 & 10 & 16 & 16 \\
2 & 46 & 23 & 81 & 40 & 57 & 29 \\
3 to 5 & 58 & 14 & 102 & 24 & 70 & 18 \\
6 to 8 & 75 & 11 & 115 & 17 & 94 & 18 \\
9 or more & 76 & 8 & 140 & 13 & 111 & 11 \\
\cline { 2 - 7 } & & 12 & 111 & 18 & 80 & 15 \\
$\begin{array}{l}\text { Average for all fam- } \\
\text { ilies }\end{array}$ & 62 & 12 & & & &
\end{tabular}

Analysis of all consuming houscholds indicated an average income elasticity of household demands for yams of $0.11 \mathrm{~s}$ and a coefficient of family size of 0.397 . For sweet potatoes, the income elasticity and family size coefficient were 0.246 and 0.213 for all families, respectively. The family-size coefficient shows the influence of conomies of scale: The pereentage increase in amount of sweet potatoes and yams consumed as a family increases in size is less than the percentage growth in family size. From the less-than-unity income clasticity it is inferred that although the average amount of sweet potatoes and yams consumed by households will increase as income is augmented, the percentage increase will be much less than the given change in income. However, there is a likelihood that, 
among urban families, the influence of income on consumption of both sweet potatoes and yams will diminish as increases occur in income levels. This is inferred from the semi-logarithmie models selected to approximate the consumption function for said products in urban areas. Calculated with income held at its mean for all urban households, income elasticity of demand among city families was 0.254 , for sweet potatoes and 0.150 for yams. For rural families, only income provided a statistically significant coefficient in the estimation of a consumption function for sweet potatoes and yams. Income elasticity of demand among rural families was 0.385 for sweet potatoes and 0.424 for yams.

TABLE 3.-Resulls of multiple regression analysis, according to model

\begin{tabular}{|c|c|c|c|}
\hline Item & Model & Equation & $R^{2}$ \\
\hline \multicolumn{4}{|l|}{ Yams } \\
\hline All familjes & Logarithmic & Log $Y=1.02+\underset{(0.056)}{0.118^{*}} \log X_{1}+\underset{(0.106)}{0.397^{* *}} \log X_{2}$ & $0.048 * *$ \\
\hline Urban families & Semi-log:ırithmic & $Y=-27.66+\underset{(8.04)}{16.53 *} \log X_{1}+\underset{(15.17)}{51.04^{* *}} \log X_{2}$ & $.062^{\bullet \bullet}$ \\
\hline Rural families & Logarithmic & $\log Y=0.624+\underset{(0.099)}{\log 0.385^{* *}} X_{2}$ & $.089^{* *}$ \\
\hline \multicolumn{4}{|l|}{ Sweet potatoes } \\
\hline All families & Logaritlımic & $\log Y=\underset{(0.053)}{0.653}+\underset{(0.089)}{0.246^{* *}} \log X_{1}+\underset{\left(0.213^{* *}\right.}{0} \log X_{2}$ & $.009^{* *}$ \\
\hline Ürban families & Semi-logarithmic & $Y=40.57+\underset{(7.28)}{22.84^{* *}} \log x_{1}+\underset{(12.27)}{37.27^{* *}} \log X_{2}$ & $.084^{* *}$ \\
\hline Rural families & Logarithmic & $\log Y=0.320+\underset{(0.095)}{0.424^{* *}} \log X_{1}$ & $.110^{* *}$ \\
\hline
\end{tabular}

1 Numbers in parentheses refer to standard error.

- Significant at 5-percent level.

* Significant at 1-percent level.

\section{DISCUSSION}

The low ratio of explanation computed for the cross-sectional data of the study suggests that there are a number of factors besides income and family size that heavily influence the consumption of sweet potatoes and yams by households. For instance, there is a great deal of difference among houscholds simply because of habit, custom, preference, social status, health, age, and other personal factors that constitute nuisance variables but that have an effect on consumption independent of income or family size. Inexact observations may constitute another source of variation. ${ }^{3}$ A low ratio of explained variation may also be traced to the fact that

${ }^{3}$ An attempt was made to discard freak values by screening the data through the Cheauvenett test (3). 
household expenditures on sweet potatoes and yams constitute only a small proportion of household income. Individual randomness is, however, of secondary interest. The relevant question is whether or not the coefficients are biased by omission of explanatory variates. Pure random variability, regardless of its magnitude, docs not bias the parameter estimates. The purpose of this study was to obtain the best possible statistical estimate of the model, without taking into account other important variables and it may be inherent in the nature and psychology of consumption that random variation among houscholds is not small $(3,4,5)$.

Although the amount of explained variation was low, all coefficients of income elasticity and family size were significant, of the expected sign, had relatively low standard errors, and were of reasonable magnitude. Further, the value and significance of the income coefficient remained relatively stable as additional variables were included in the regression equations. This tends to demonstrate that there is a clearly defined relationship between family income and the purchase of sweet potatoes and yams, even though this relationship accounts for only a small proportion of the total variation in consumption. Moreover, the relatively low standard errors suggest some degree of confidence in the computed coefficients. Although caution must always be exercised in the use and interpretation of results, it is felt that the coefficients herein presented provide acceptable estimates of the income elasticities of demand for sweet potatoes and yams.

\section{SUMMARY}

The purpose of this study was to determine the income-consumption elasticity of household demand for sweet potatoes and yams in Puerto Rico, and to examine the nature and extent of the relationship between houschold consumption of these products and selected socio-economic variables.

The analysis is based on data from a sample of 1,021 family records obtained by the method of personal interview from a cross-section of the population of Puerto Rico, during 1962.

The method of analysis was the least-squares regression approach. Four basic models were fitted to the consumption data. The basic models initially included income as the only regressor, but were modified into multiple regression model by the subsequent addition of other variables.

Analysis of all consuming households indicated an average income elasticity of demand for yams of 0.118 and coefficient of family size of 0.397. For sweet potatoes, the income elasticity and family size coefficients were 0.246 and 0.213 for all families, respectively. Low income elasticities show that even with dramatic improvements in real family income, the expected 
change in consumption due to the income effect will be relatively small and largely overshadowed by anticipated decreases in average family size in Puerto Rico. Variables other than family size and income had little or no measurable effect on houschold consumption of sweet potatoes and yams.

\section{RESUMEN}

El propósito de este estudio fue estimar los coeficientes de elasticidad ingresocompra y tamaño de la familia-compra respecto a la batata y el ñame y examinar la naturaleza y magnitud de la relación entre la compra de estos dos comestibles por las amas de casa y ciertas variables socio-económicas seleccionadas.

El estudio se basa en los datos recopilados mediante una encuesta que se hizo entrevistando una muestra de 1,021 familias residentes en Puerto Rico en 1962.

El análisis de los datos se hizo mediante el método estadístico de regresión mínima cuadrática. Se ajustaron cuatro ecuaciones lineales a los datos, en las que el ingreso fue la única variable independiente, y subsiguientemente se añadieron a la primera ecuación otras variables socio-económicas tales como tamaño de la familia, etc.

Los resultados del análisis estadístico para las familias entrevistadas que informaron haber comprado el producto indican un coeficiente de elasticidad ingreso-compra de 0.118 para el name y 0.246 para la batata. Por otro lado, los coeficientes que expresan la elasticidad tamaño de la familia-compra indican un valor de 0.397 para el ñame, y 0.213 para la batata. Los bajos coeficientes de elasticidad ingreso-compra parecen indicar que aunque mejore sustancialmente el ingreso real de la familia, se espera que el cambio respecto al consumo de estos dos productos a consecuencia de un aumento en el ingreso sea insignificante. Además, dicho aumento en cl consumo también sería anulado porque se anticipa una disminución en el tamaño de la familia en Puerto Rico. Otras variables, aparte del ingreso y del tamaño de la familia, tuvieron poco o ningún efecto significativo sobre la compra de la batata y el ñame.

\section{LITERATURE CITED}

1. Anuario de Estadísticas Agrícolas de Puerto Rico, The Commonwealth of Puerto Rico, Dept. Agr., p. 54, Dec. 1969.

2. Klein, L. R., An Introduction to Econometrics, Prentice-Hall, Inc., Englewood Cliff, N.J., p. 31, 1963.

3. Mellor, J., Higher Mathematies for Students of Chemistry and Physies, Dober Brothers, New York, N.Y., pp. 563-(i23, 1946.

4. Purcel, J. C., Personal communication to the junior author, No. 1, 1967.

5. Wold, H. and Juréen, L., Demand Analysis, John Wiley and Sons, Inc., New York, N.Y., p. 71, 1953. 